\title{
Optimization of Hot-pressing Technique for Genuine Full-grain Leather Made of Natural Rubber Latex
}

\author{
Yinghua $\mathrm{Ma}^{1,2^{*}}$, Shaolan Ding ${ }^{1}$, Dongsheng Xin ${ }^{2}$, Fei Ma ${ }^{1}$, Runting Xia ${ }^{2}$ \\ ${ }^{1}$ College of Bioresources Chemical \& Materials Engineering, Shaanxi University of Science \& Technology, Xi'an 710021, \\ China \\ ${ }^{2}$ Department of Garment Engineering, Xingtai Polytechnic College, Xingtai 054000, China
}

Corresponding Author Email: yinghuama@yeah.net

https://doi.org/10.18280/acsm.430305

Received: 18 March 2019

Accepted: 30 May 2019

\section{Keywords:}

natural rubber latex, genuine full-grain leather (GFGL), hot-pressing technique, physical-mechanical properties

\begin{abstract}
Currently, the waste shavings are either directly recycled to produce regenerated leather or used to extract collagen. Both methods are complex and unfriendly to the environment. This paper aims to recycle waste chrome shavings in a clean, simple and low-consumption manner. For this purpose, the hot-pressing method was selected to prepare genuine full-grain leather (GFGL) plates. Then, the author probed into the influencing factors and their impacts of hotpress forming and the physical-mechanical properties of the preliminary plates, i.e. the hotpressing products of prefabricated plates. Through the research, the optimal hot-pressing conditions and formula for GFGL plates made of natural rubber latex were determined as: (1) latex ratio $15 \%$, water ratio $2: 1,110{ }^{\circ} \mathrm{C}, 6 \mathrm{~min}$ and $5 \mathrm{MPa}$; (2) latex ratio $21 \%$, water ratio 2.5:1, $100{ }^{\circ} \mathrm{C}, 4 \mathrm{~min}$ and $5 \mathrm{MPa}$. Note that the latex ratio refers to the ratio of latex weight to the total weight of shavings and latex, and the water ratio refers to the weight ratio of water to latex.
\end{abstract}

\section{INTRODUCTION}

The statistics of the UK Leather Trade Federation show that only $20 \%$ of tanning materials are converted into leather. Even if the lining leather is considered, the utilization rate only increases to $31.5 \%[1,2]$. The other materials become solid wastes through such operations as splitting, shaving, trimming and buffing. Each ton of wet-salted hides can only produce $200 \mathrm{~kg}$ of finished leather, while leaving over $600 \mathrm{~kg}$ of solid wastes [3]. If not treated properly, these solid wastes will cause severe environmental pollution, and a huge waste of resources like high-quality collagen and chromic oxide [4]. As a result, a growing attention has been paid to the rational treatment and thorough utilization of these solid wastes, making the machining process clean and the products more valuable [5].

The existing studies on leather waste treatment mainly focus on extracting collagen and producing regenerated leather from the solid wastes [6]. One the one hand, collagen can be extracted either directly or indirectly from chrome shavings. The direct methods utilize chromium and collagen comprehensively, without separating them; the indirect methods separate and purify chromium and collagen, and makes use of them separately [7]. The indirect methods mainly include the following operations: pretreatment of chromiumcontaining wastes, dechroming and collagen extraction, separation and purification, concentration, drying and detection, and packaging. Dechroming is the key to collagen extraction. The dechroming effect directly bears on the product quality [8]. Based on the chromium remover or treatment agent, the collagen extraction strategies can be divided into acid method, alkali method, oxidation method, ultrasonic method, enzymatic method, acid-alkali alternating method, etc. [9]. Among them, the acid method deeply hydrolyzes collagen and only yields small molecules of collagen degradation products; what is worse, the equipment may be corroded by the acid, yet the chromium cannot be fully removed [10]. The alkali method features a long cycle, serious pollution, and large lime consumption; the collagen thus extracted is highly hydrolyzed, containing lots of ash and chromium [11]. The oxidation method produces toxic hexavalent chromium ions, which greatly harm the environment; the liquid waste of dechroming must be further treated [12]. The enzymatic method generates collagen hydrolysates with a small molecular weight, and requires dechroming in advance, failing to achieve a high removal rate of chromium; in addition, the collagen is severely degraded, the yield is low and the process is hard to control [13]. The collagens obtained by the above methods have mainly been applied in industries like leather, paper, food, medicine, cosmetics, feed, fertilizer, green fiber, etc. However, leather wastes contain so many harmful substances that they are not suitable for food, medicine, cosmetics or stock farming, even after precise purification and treatment.

On the other hand, the production of regenerated leather is inspired by paper-making. Firstly, various leather fibers are extracted from the shavings via plant tanning or chrome tanning, mixed with plant fibers like cotton, linen and wood fibers (the cotton and linen fibers mainly come from the cloth selvages and corners of sewing factories, the spinning wastes of textile factories, and various cotton and linen wastes [14]; the wood fibers are obtained from waste paper stock of paper mills and fiber pulp of low-grade paper), and then treated with chemical reagents and binders [15]. After that, a large amount of water is added, turning the mixture into a slurry. Next, the slurry is filtered by a metal sieve to remove water. Once the slurry is fully dried, it is possible to get laminated bonded 
fiberboards. The production process includes the following steps: selection of shavings and cotton fibers via screening and magnetic separation, weighing, pretreatment, crushing, rough grinding, fine grinding, slurry emulsification, preparation of mixed slurry, water removal by extrusion, forming, drying, sorting, and finishing. Apart from its high complexity, the production of regenerated leather generates wastewater containing various adhesives and compounding agents, causing secondary pollution to the environment [16]. Moreover, the finished products are not suitable for producing shoes, bags and similar items, because they are light in weight, weak in strength and elasticity, and poor in resistance to warping, temperature, wear and tear.

This paper attempts to recycle waste chrome shavings in a clean, simple and low-consumption manner. Firstly, the author selected the hot-pressing method to prepare genuine full-grain leather (GFGL) plates, and explored the influencing factors and their impacts of hot-press forming and the physicalmechanical properties of the preliminary plates, i.e. the hotpressing products of prefabricated plates. The exploration reveals that the main influencing factors include latex ratio (the ratio of latex weight to the total weight of shavings and latex), water ratio (the weight ratio of water to latex), hotpressing temperature, hot-pressing time and hot-pressing pressure. The range of each factor was optimized through single factor tests. Then, the optimal combination of these factors was determined through orthogonal test, coupled with the physical-mechanical properties and microstructure of the finished products.

\section{METHODOLOGY}

\subsection{Main materials}

(1) Chrome shavings. The wet blue chrome shavings obtained via cowhide production were selected for this research. The shavings were placed in a drying oven for $1 \mathrm{~h}$ at $45^{\circ} \mathrm{C}$ to reduce the water content within $10 \%$, making it possible to strictly control the subsequent screening and hotpressing conditions

Considering their variation in size and shape, the directly recovered shavings were screened by different types of sieves. The screening shows that the shavings can be divided into the following categories: large strips of curled shavings, the shavings that can pass \#8-mesh sieve, the shavings that can pass \#30-mesh sieve, and that shavings that can pass \#50-mesh sieve. Then, the author observed the microstructure of each type of shavings and tested the physical-mechanical properties of preliminary plates made of these shavings. It is learned that the curled shavings are too large, while the 30- and 50-mesh shavings are too fragmented. By contrast, the 8-mesh shavings have a medium size, and retain the original form of the collagenous fiber. In addition, the finished plates made of the 8-mesh shavings exhibited excellent physical-mechanical properties. Therefore, the 8 -mesh shavings were taken as the raw materials.

Figures 1-4 present the macroscopic appearance and the microstructures magnified by 10,000, 5,000 and 2,000 times of the 8-mesh shavings, respectively. To ensure the consistency of the hot-pressed plates, every plate was prefabricated with $30 \mathrm{~g}$ shavings.

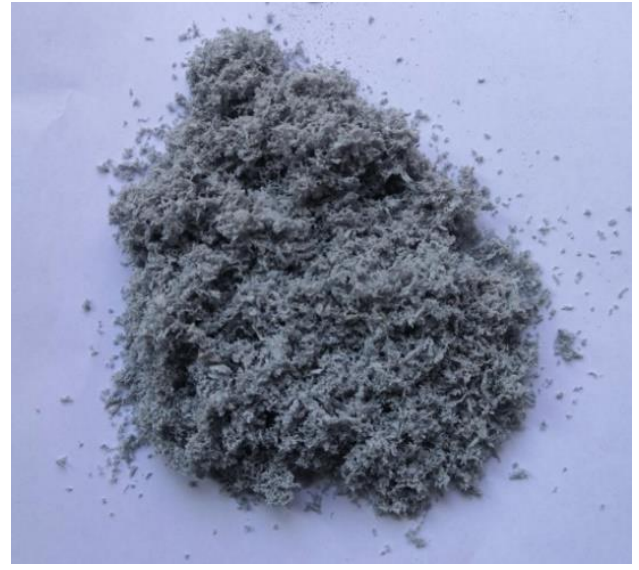

Figure 1. The macroscopic appearance of the 8-mesh shavings

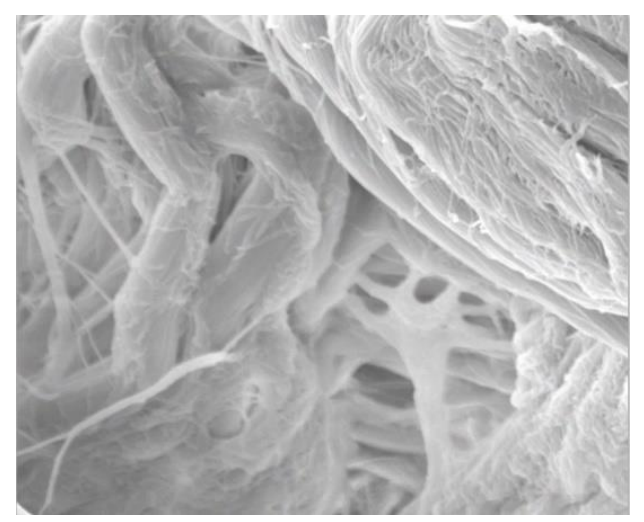

Figure 2. The microstructure of the 8-mesh shavings magnified by 10,000 times

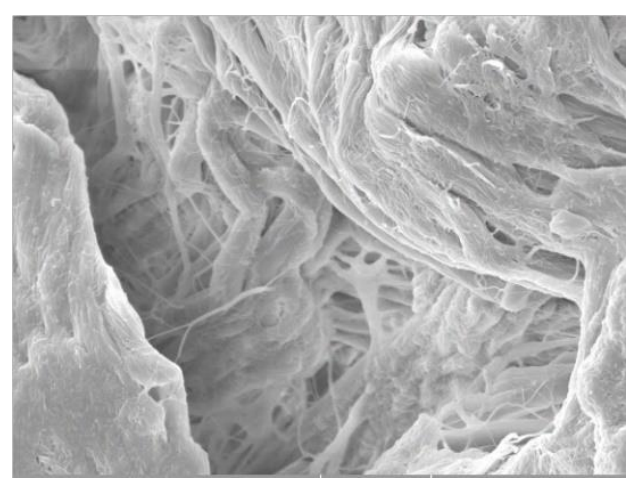

Figure 3. The microstructure of the 8-mesh shavings magnified by 5,000 times

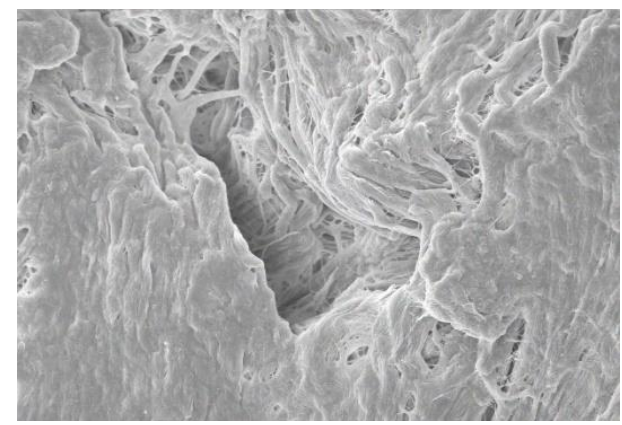

Figure 4. The microstructure of the 8-mesh shavings magnified by 2,000 times 
(2) Natural rubber latex. This research uses the high ammonia (HA) latex, with a dry rubber content (DRC) of $60 \%$, produced by Thai Hua Rubber Public Company Limited. The latex, fabricated in a clean and simple process, is a natural rubber adhesive with no toxicity, good compatibility with collagenous fiber, high hydrophilicity and stable performance. The main properties of the latex are listed in Table 1 below.

Table 1. The main properties of the latex

\begin{tabular}{cccc}
\hline Properties & Results & \multicolumn{2}{c}{$\begin{array}{c}\text { Specifications as per } \\
\text { ISO 2004: 1979E }\end{array}$} \\
\cline { 3 - 4 } & & \multicolumn{2}{c}{ FG-HG } \\
\hline $\begin{array}{c}\text { Total solids content } \\
\text { (TSC) wt\% }\end{array}$ & 61.81 & 61.50 & Min \\
$\begin{array}{c}\text { Dry rubber content } \\
\text { (DRC) wt\% }\end{array}$ & 60.26 & 60.00 & Min \\
$\begin{array}{c}\text { Non-rubber solids \% } \\
\text { Ammonia content (on } \\
\text { total weight) \% }\end{array}$ & 1.55 & 2.00 & Max \\
$\begin{array}{c}\text { Ammonia content (on } \\
\text { water phase) \% } \\
\text { pH at } 25^{\circ} \mathrm{C}\end{array}$ & 0.69 & 0.60 & Min \\
$\quad 1.81$ & - & - \\
$\begin{array}{c}\text { KOH number } \\
\text { Volatile fatty acid (VFA) } \\
\text { number }\end{array}$ & 0.62 & - & - \\
$\begin{array}{c}\text { Mechanical stability } \\
\text { time @ 55\% TS, sec. }\end{array}$ & 866 & 650.00 & Min \\
Magnesium content on \\
solids, ppm
\end{tabular}

\subsection{Hot-press forming process}

(1) Prefabrication. The previous tests show that, after the latex was poured into the shavings, the two materials reacted quickly and bonded tightly in local areas. Hence, the plates were prefabricated in the following steps:

First, a proper amount of latex was poured into the beaker. Then, 30g 8-mesh shavings were added into the beaker. The mixture was stirred evenly with a glass rod immediately. After that, the mixture was relocated into a $33.5 \mathrm{~mm} \times 33.5 \mathrm{~mm}$ rigid frame mold, which was on a Teflon film. The mixture was flattened evenly with a glass rod, covered with a $33.5 \mathrm{~mm} \times 33.5 \mathrm{~mm}$ Teflon film, and then preformed through repeated punching with a hammer. The prefabricated plate was transferred onto the lower steel plate and covered with the upper steel plate, waiting to be hot-pressed.

(2) Hot-pressing. The prefabricated plate, sandwiched between the upper and lower steel plates, was placed on a flat vulcanizing machine, and hot-pressed at the test temperatures, pressures and times. The flat vulcanizing machine (model: XLB-D400*600*2/0.5MN) was produced by Qingdao Yahua Machinery Co., Ltd., Shandong Province, China.

\subsection{Measurement of physical-mechanical properties}

The focus of our test is the basic hot-pressing technique for GFGL plates made of natural rubber latex. Therefore, the tensile strength, bursting strength, gas permeability and water absorption of the preliminary plates were measured and characterized by the following instruments and methods.

The tensile strength, elongation at break, bursting strength and bursting height were tested on a universal testing machine (UTM). The gas permeability was captured by a H.C. Fedorov detector of leather air permeability. The mass percent of the absorbed water to the total specimen was measured with a kubelka apparatus after the plate had been soaked in the specified amount of water for $15 \mathrm{~min}$ and $24 \mathrm{~h}$, respectively, at the required temperature.

\subsection{Microstructure observation}

The microstructure of the GFGL plates was observed by environmental scanning electron microscopy (ESEM) with the magnification of 3,000 and 6,000 times, respectively, to further reveal how the physical-mechanical properties of preliminary plates are affected by different levels of adhesive dosage, hot-pressing temperature, hot-pressing time and hotpressing pressure.

\section{RESULTS ANALYSIS}

\subsection{Single factor test}

3.1.1 The optimal ranges of hot-pressing factors based on formability, hot-pressing conditions, and appearance

(1) The optimal range of hot-pressing temperature. The results on samples A1 3 show that, after the addition of shavings, the HA natural rubber latex was clotted locally before stirring. To facilitate the processing and ensure the uniformity of preliminary plates, a certain proportion of purified water was added to the HA natural rubber latex.

The results on samples B1 3 demonstrate the significant impacts of hot-pressing temperature on the forming of the prefabricated plate, revealing that hot-press forming is infeasible at below $60^{\circ} \mathrm{C}$. When the temperature was lower than $60^{\circ} \mathrm{C}$, the natural rubber latex did not react with the shavings, which were dispersed and not bonded with the adhesive.

Then, the results on samples $\mathrm{C} 1 \sim 4$ were discussed to further explore the effects of high temperature on preliminary plates. It is learned that the prefabricated plates were hot-pressed into black circles, giving off the smell of burnt shavings, when the hot-pressing temperature reached $120^{\circ} \mathrm{C}$.

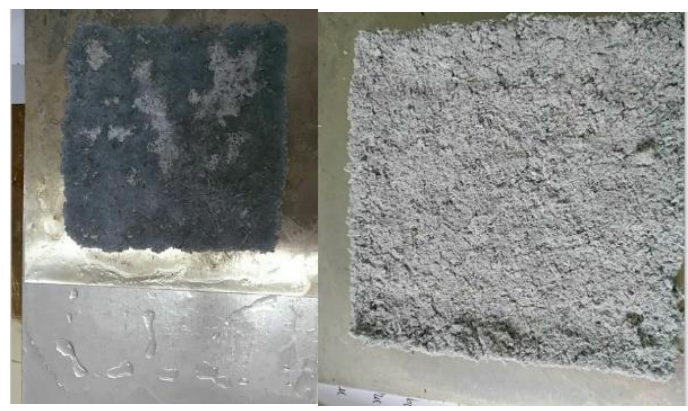

(1) Sample C5

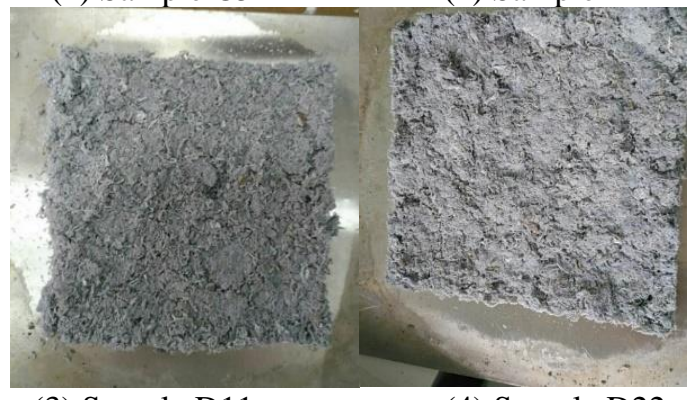

(3) Sample D11
(4) Sample D22
Figure 5. The photos on typical samples after hot-pressing 
On this basis, the results at the hot-pressing temperature at $117{ }^{\circ} \mathrm{C}$ were examined, revealing that the prefabricated plates were also shaped like black circles, giving off the smell of burnt shavings. In addition, the results at $75^{\circ} \mathrm{C}$ and $85^{\circ} \mathrm{C}$ show that droplets remained on the press plate, while the preliminary plate stuck to the steel plates; the center of the preliminary plate was dry, the peripherals were wet blue, like the original shavings, and the shavings were scattered (Figure 5(1)). This is because the moisture cannot be completely volatized at such low hot-pressing temperatures.

Through the above analysis, the optimal range of hotpressing temperature was identified as $90 \sim 110{ }^{\circ} \mathrm{C}$.

(2) The optimal range of latex ratio. The results on D2, D5, D12, D17 and D22 show that the shavings were not well preformed at the latex ratio of $12 \%$. Under this ratio, the shavings were crumbs or floes and crumbs; the bluish color of the shavings was retained on the prefabricated plate, and some shavings fell off from the plate. When the latex ratio increased to $15 \sim 21 \%$, the preformation improved, and the shavings existed as floes or floes and threads. When the latex ratio further grew to $23 \%$, the shavings combined widely into floes with a few threads or clots. In this case, the typical forms of the plates are shown in Figures 5(2)-(4).

Further analysis of $\mathrm{C} 4$ reveals that the plate was sticky and filaments appeared when the plate was bent. The filaments were rubber threads. Hence, the latex ratio of $25 \%$ is a little too high, and leads to a rise in cost.

In view of the above, the optimal range of the latex ratio was defined as $15 \sim 23 \%$.

Table 2. The formability, hot-pressing conditions, and appearance of samples

\begin{tabular}{|c|c|c|c|c|c|c|c|c|}
\hline $\begin{array}{l}\text { Sample } \\
\text { number }\end{array}$ & $\begin{array}{l}\text { Latex } \\
\text { ratio, } \\
\%\end{array}$ & $\begin{array}{l}\text { Water } \\
\text { ratio }\end{array}$ & $\begin{array}{l}\text { Hot-pressing } \\
\text { temperature, }{ }^{\circ} \mathrm{C}\end{array}$ & $\begin{array}{l}\text { Hot-pressing } \\
\text { time, min }\end{array}$ & $\begin{array}{l}\text { Hot-pressing } \\
\text { pressure, } \\
\text { MPa }\end{array}$ & $\begin{array}{c}\text { Formability of } \\
\text { prefabricated plate }\end{array}$ & $\begin{array}{l}\text { Hot-pressing } \\
\text { conditions }\end{array}$ & $\begin{array}{c}\text { Appearance of } \\
\text { preliminary plate }\end{array}$ \\
\hline A1 & 15 & $0 ; 1$ & 90 & 3 & 3 & $\begin{array}{l}\text { Rapid reaction and clots } \\
\text { in local areas, but loose } \\
\text { globally }\end{array}$ & - & $\begin{array}{l}\text { Hard plate in local } \\
\text { glued areas, and loose } \\
\text { shavings in unglued } \\
\text { areas }\end{array}$ \\
\hline $\mathrm{A} 2$ & 20 & $0: 1$ & 90 & 6 & 3 & $\begin{array}{l}\text { Rapid reaction, floes and } \\
\text { clots in local areas, but } \\
\text { loose globally }\end{array}$ & Not hot-pressed & 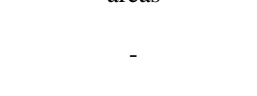 \\
\hline A3 & 25 & $0 ; 1$ & 90 & 6 & 3 & $\begin{array}{l}\text { Rapid reaction, floes and } \\
\text { clots in local areas, but } \\
\text { loose globally }\end{array}$ & Not hot-pressed & - \\
\hline B1 & 15 & 1: 1 & 60 & 4 & 6 & Loose but in shape & - & Not in shape \\
\hline $\mathrm{B} 2$ & 20 & $1: 1$ & 90 & 2 & 6 & Loose but in shape & - & In shape \\
\hline B3 & 25 & 1: 1 & $\begin{array}{c}\text { Normal } \\
\text { temperature }\end{array}$ & 6 & 6 & Loose but in shape & - & Dry and loose \\
\hline $\mathrm{C} 1$ & 20 & 1: 1 & 90 & 6 & 3 & Floes & - & \\
\hline $\mathrm{C} 2$ & 20 & $0.5: 1$ & 120 & 6 & 3 & Clots & - & Black, burnt smell \\
\hline $\mathrm{C} 3$ & 25 & 1: 1 & 120 & 6 & 3 & Floes & - & $\begin{array}{c}\text { Black, burnt smell, } \\
\text { sticky plate (Figure C3) }\end{array}$ \\
\hline $\mathrm{C} 4$ & 25 & $0.5: 1$ & 90 & 6 & 3 & Clots & - & Sticky plate \\
\hline D1 & 12 & $0.5: 1$ & 90 & 5 & 3 & Crumbs, not in shape & - & - \\
\hline D2 & 12 & $1: 1$ & 100 & 6 & 5 & $\begin{array}{l}\text { Floes and crumbs, in } \\
\text { shape }\end{array}$ & - & - \\
\hline D3 & 12 & $1.5: 1$ & 110 & 7 & 7 & $\begin{array}{l}\text { Floes and threads, in } \\
\text { shape }\end{array}$ & - & - \\
\hline D4 & 12 & $1.5: 1$ & 100 & 6 & 3 & $\begin{array}{l}\text { Floes and threads, in } \\
\text { shape }\end{array}$ & - & - \\
\hline D5 & 15 & $0.5: 1$ & 90 & 6 & 5 & Floes, dry, in shape & - & - \\
\hline D6 & 15 & $1: 1$ & 100 & 7 & 7 & Floes, in shape & - & - \\
\hline D7 & 15 & $1.5: 1$ & 110 & 5 & 3 & Floes, in shape & - & - \\
\hline D8 & 15 & $0.5: 1$ & 100 & 7 & 3 & Floes, dry, in shape & - & - \\
\hline D9 & 15 & 1: 1 & 110 & 5 & 5 & Floes, in shape & - & - \\
\hline D10 & 15 & 1.5: 1 & 90 & 6 & 7 & Floes, in shape & - & Sticky steel plates \\
\hline D11 & 15 & $1.5: 1$ & 100 & 4 & 4 & $\begin{array}{c}\text { Floes, dispersed, but in } \\
\text { shape }\end{array}$ & - & - \\
\hline D12 & 15 & 2: 1 & 110 & 3 & 4 & $\begin{array}{l}\text { Mixed floes and clots, in } \\
\text { shape }\end{array}$ & $\begin{array}{l}\text { A few droplets } \\
\text { on steel plates }\end{array}$ & $\begin{array}{l}\text { In good shape, } \\
\text { compacted and dry }\end{array}$ \\
\hline D13 & 15 & $2.5: 1$ & 100 & 5 & 4 & $\begin{array}{l}\text { Floes with a few } \\
\text { threads, in shape }\end{array}$ & - & $\begin{array}{l}\text { In good shape, } \\
\text { compacted and dry }\end{array}$ \\
\hline D14 & 18 & $1.5: 1$ & 110 & 5 & 4 & - & $\begin{array}{l}\text { Droplets on steel } \\
\text { plates }\end{array}$ & $\begin{array}{l}\text { Compacted and hard } \\
\text { plate }\end{array}$ \\
\hline D15 & 18 & $2.5: 1$ & 90 & 3 & 4 & - & $\begin{array}{l}\text { Droplets on press } \\
\text { plate }\end{array}$ & $\begin{array}{l}\text { Dry in the center and } \\
\text { wet blue on the } \\
\text { peripherals }\end{array}$ \\
\hline D16 & 21 & $0.5: 1$ & 100 & 5 & 7 & $\begin{array}{l}\text { Floes, scattered, in } \\
\text { shape }\end{array}$ & - & - \\
\hline D17 & 21 & 1: 1 & 110 & 6 & 3 & $\begin{array}{c}\text { Floes with a few clots, } \\
\text { in shape }\end{array}$ & - & - \\
\hline D18 & 21 & $0.5: 1$ & 110 & 6 & 7 & $\begin{array}{l}\text { Floes, scattered, in } \\
\text { shape }\end{array}$ & - & - \\
\hline D19 & 21 & 1: 1 & 90 & 7 & 3 & $\begin{array}{l}\text { Floes with a few } \\
\text { threads, in shape }\end{array}$ & - & - \\
\hline D20 & 21 & $1.5: 1$ & 90 & 5 & 5 & Clots, in good shape & $\begin{array}{l}\text { Lots of water on } \\
\text { press plate }\end{array}$ & Sticky steel plates \\
\hline D21 & 23 & 2: 1 & 90 & 5 & 4 & Dispersed, not in shape & $\begin{array}{l}\text { Lots of water on } \\
\text { press plate and } \\
\text { steel plates }\end{array}$ & Good in shape \\
\hline D22 & 23 & $2.5: 1$ & 110 & 4 & 4 & $\begin{array}{c}\text { Clots with a few floes, } \\
\text { best in shape }\end{array}$ & - & $\begin{array}{l}\text { Slightly deformed, stiff } \\
\text { and smooth }\end{array}$ \\
\hline
\end{tabular}


(3) The optimal range of water ratio. The results on samples D5 13 (latex ratio: $15 \%$ ) show that, when the water ratio was 0.5 : 1 , the shavings were dry and hard to be stirred evenly, while the plates were not well preformed. When the water ratio was $2.5: 1$, the shavings could be stirred evenly quickly without releasing heat, and the plates were well preformed. This means moisture promotes the bonding between shavings and latex. Of course, the temperature and time of hot-pressing should be increased to volatize the excess moisture.

The results on samples D16 22 (latex ratio: $18 \%$ or $21 \%$ ) show that, when the water ratio was $0.5: 1$, the shavings were dispersed, and the plates were poorly preformed. When the water ratio was $2.5: 1$, the shavings could be stirred evenly quickly, and the plates existed in the form of stable clots. In this case, the temperature and time of hot-pressing should also be increased to volatize the excess moisture.

In light of the above, the optimal range of water ratio was set to 1: 1 2.5: 1 .

(4) The optimal range of hot-pressing pressure. Comparing the results between $\mathrm{B} 2$ and $\mathrm{A} 1$, it is discovered that the hotpressing pressure affects the plate thickness and shape, but has nothing to do with the plate compactness. This is attributable to the good fluidity of natural rubber latex. Under a high pressure, the plates became thinner, changing from square shape to circular shape. This trend is particularly prominent in D3 and D6: the plates were thinned and severely deformed at the pressure of $7 \mathrm{MPa}$ and at the time of $7 \mathrm{~min}$. Hence, $7 \mathrm{MPa}$ is too large for hot-press forming. Therefore, the optimal range of hot-pressing pressure was determined as $3 \sim 6 \mathrm{MPa}$.

(5) The optimal range of hot-pressing time. Results analysis shows that the hot-pressing time had insignificant impacts on the physical-mechanical properties of the preliminary plates. However, it takes time for the moisture to volatize in the hotpressing process. Hence, the optimal range of hot-pressing time was set to $4 \sim 7 \mathrm{~min}$.

3.1.2 The optimal range of hot-pressing factors based on the physical-mechanical properties

The physical-mechanical properties of the preliminary plates with relatively good appearance in Table 2 were measured. The measured results on tensile strength, elongation at break, gas permeability, $15 \mathrm{~min}$ water absorption and $24 \mathrm{~h}$ water absorption is displayed in Figures $6 \sim 10$, respectively.

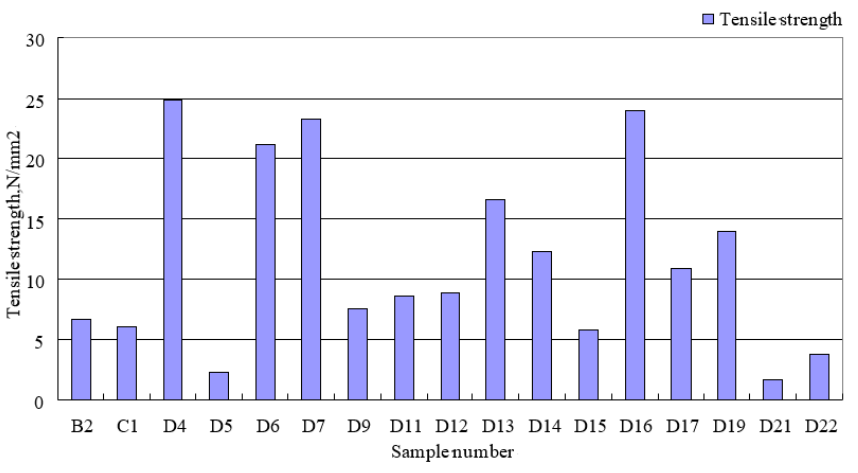

Figure 6. Tensile strength

As shown in Figure 6, D4, D6, D7, D13, D16 and D19 had relatively high tensile strength, while D5, D15, D21 and D22 had relatively poor resistance to tensile force. Thus, it can be concluded that the tensile strength is affected by the interaction between the latex ratio, water ratio, hot-pressing temperature, hot-pressing time and hot-pressing pressure; the minimum tensile strength appears at the latex ratio of $23 \%$.

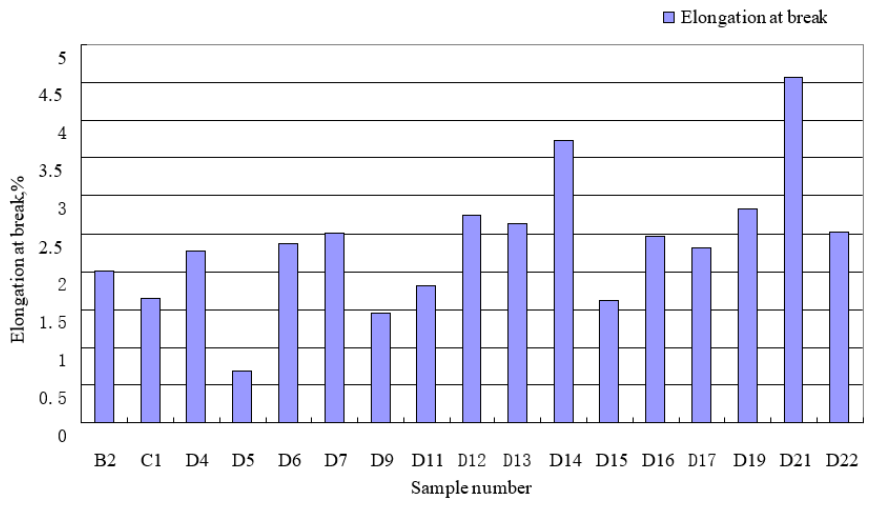

Figure 7. Elongation at break

As shown in Figure 7, D21 and D14 had relatively high elongations at break, while D5 came at the bottom in terms of this factor. The result reflects the impacts of water ratio on elongation at break: the higher the water ratio, the greater the elongation at break.

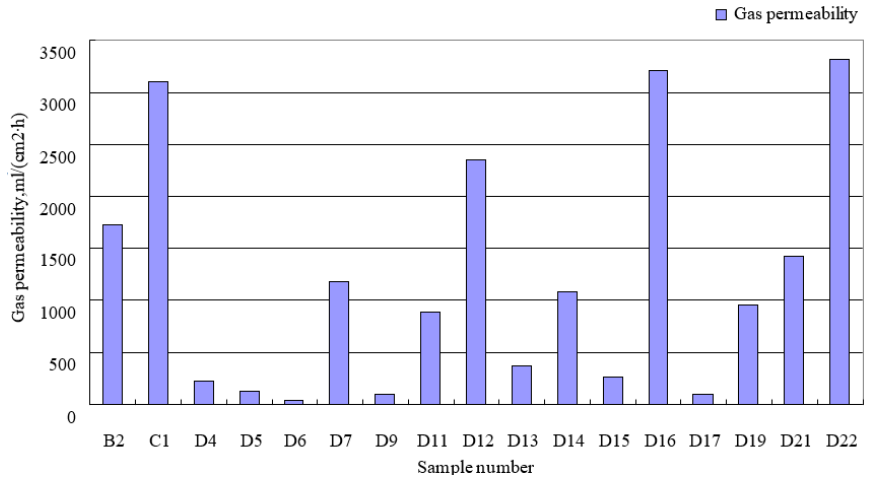

Figure 8. Gas permeability

As shown in Figure 8, good gas permeability was observed in $\mathrm{C} 1, \mathrm{D} 12, \mathrm{D} 16$ and D22, and poor gas permeability was found in D4, D5, D6, D9, D13, D15 and D17. Therefore, the gas permeability of the samples is affected by the interaction between the latex ratio, water ratio, hot-pressing temperature, hot-pressing time and hot-pressing pressure.

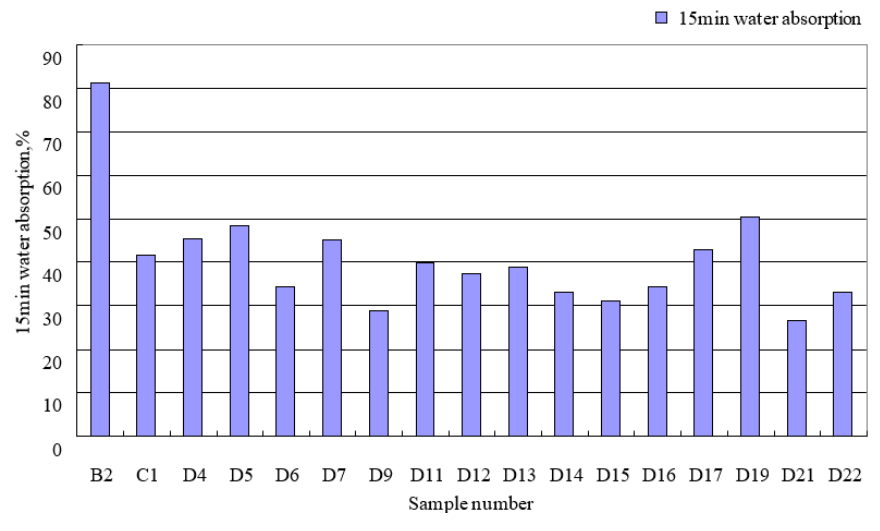

Figure 9. 15min water absorption

As shown in Figures 9 and 10, B2 was the only sample with a good water absorption at $15 \mathrm{~min}$, while the other samples were similar on water absorption. This proves that the rapid water absorption of the samples is not influenced by hotpressing factors. However, with the elapse of time, the water 
absorption of B2, D11 and D17 declined, while D5 had the same water absorption at $24 \mathrm{~h}$ as at $15 \mathrm{~min}$. The results demonstrate that the prefabricated plates can absorb water rapidly.

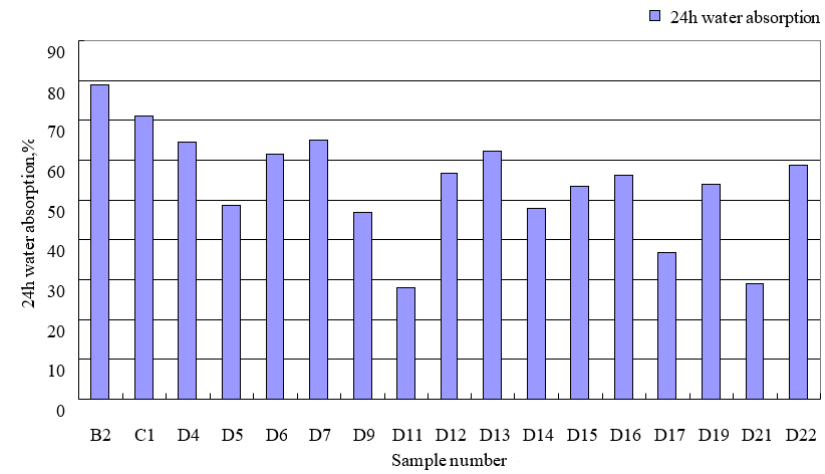

Figure 10. 24h water absorption
The above analysis on physical-mechanical properties shows that the optimal range of hot-pressing factors, which were determined based on the formability, hot-pressing conditions and appearance agree well with the properties of the preliminary plates.

\subsection{Orthogonal test}

An orthogonal test with 5 factors and 4 levels was designed based on the optimal ranges of hot-pressing factors (Table 3 ).

\subsubsection{Physical-mechanical properties analysis}

The physical-mechanical properties of the preliminary plates with relatively good appearance in Table 3 were measured. The measured results on tensile strength, elongation at break, bursting strength, bursting height, gas permeability, $15 \mathrm{~min}$ water absorption and $24 \mathrm{~h}$ water absorption is displayed in Figures 11 17, respectively.

Table 3. The 5-factor, 4-level orthogonal test

\begin{tabular}{cccccc}
\hline $\begin{array}{c}\text { Sample } \\
\text { number }\end{array}$ & Latex ratio, $\%$ & $\begin{array}{c}\text { Water } \\
\text { ratio }\end{array}$ & $\begin{array}{c}\text { Hot-pressing } \\
\text { temperature, }{ }^{\circ} \mathbf{C}\end{array}$ & $\begin{array}{c}\text { Hot-pressing time, } \\
\text { min }\end{array}$ & $\begin{array}{c}\text { Hot-pressing } \\
\text { pressure, MPa }\end{array}$ \\
\hline S-1 & 15 & $1: 1$ & 90 & 4 & 3 \\
S-5 & 15 & $2: 1$ & 110 & 6 & 5 \\
S-10 & 15 & $2.5: 1$ & 115 & 7 & 6 \\
S-9 & 18 & $1: 1$ & 100 & 6 & 6 \\
S-11 & 18 & $1.5: 1$ & 90 & 7 & 5 \\
S-12 & 18 & $2: 1$ & 115 & 4 & 4 \\
S-13 & 18 & $2.5: 1$ & 110 & 5 & 3 \\
S-14 & 21 & $1.5: 1$ & 115 & 6 & 6 \\
S-2 & 21 & $2: 1$ & 90 & 5 & 5 \\
S-6 & 21 & $2.5: 1$ & 100 & 4 & 6 \\
S-4 & 23 & $1.5: 1$ & 110 & 4 & 5 \\
S-7 & 23 & $1: 1$ & 115 & 5 & 3 \\
S-3 & 23 & $2: 1$ & 100 & 7 & 4 \\
S-8 & 23 & $2.5: 1$ & 90 & 6 & \\
\hline
\end{tabular}

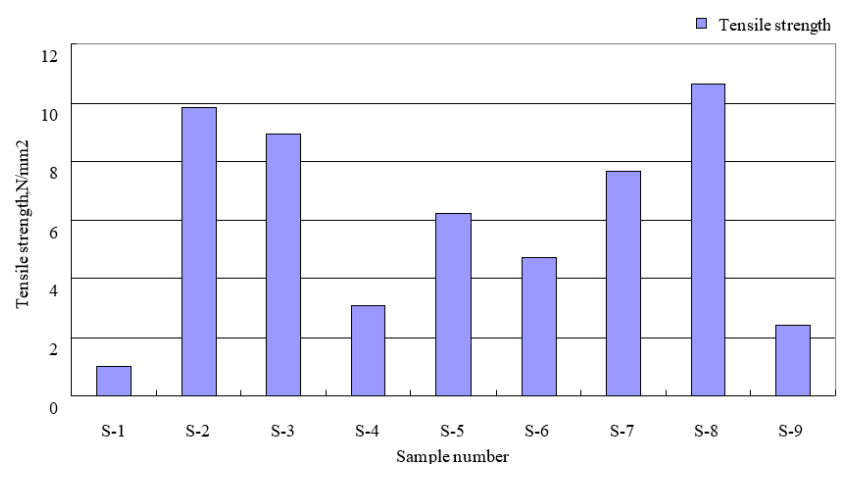

Figure 11. Tensile strength

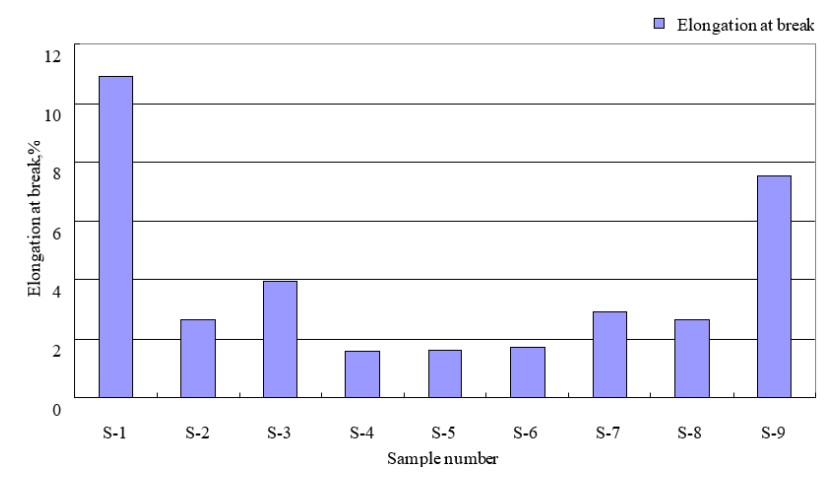

Figure 12. Elongation at break

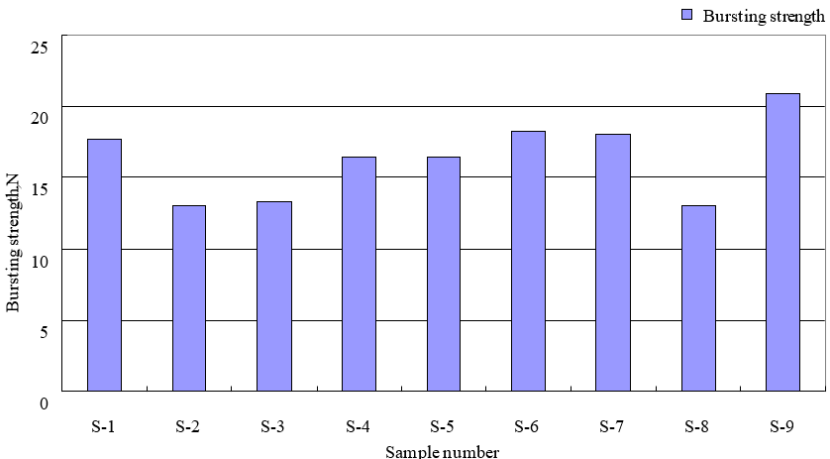

Figure 13. Bursting strength

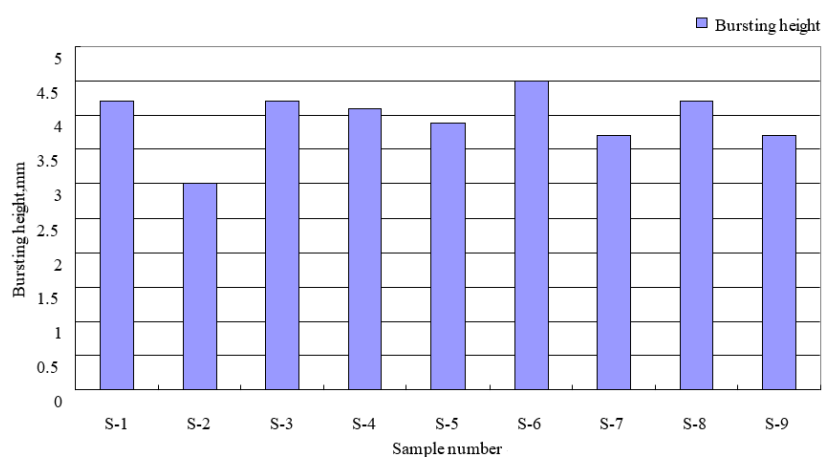

Figure 14. Bursting height 
As shown in Figure 11, S-1 and S-9 had relatively low tensile strengths, which agrees with the phenomenon that the preliminary plate stuck to the steel plate and some shavings fell of the plate. Through the analysis on hot-pressing factors, the phenomenon can be explained by the fact that the water ratio of $1: 1$ is too low for the latex to be mixed evenly with the shavings.

It can also be seen that the GFGL plates made of natural rubber latex showed relatively low tensile strength. Hence, tough plant fibers will be added to enhance the tensile strength.

Figure 12 shows that the elongation at break of the GFGL plates made of natural rubber latex is negatively correlated with their tensile strength.

Figures 13 and 14 show that the GFGL plates made of natural rubber latex boast good bursting strength, which is basically not affected by hot-pressing factors. It can be concluded that such plates are excellent materials for insole board.

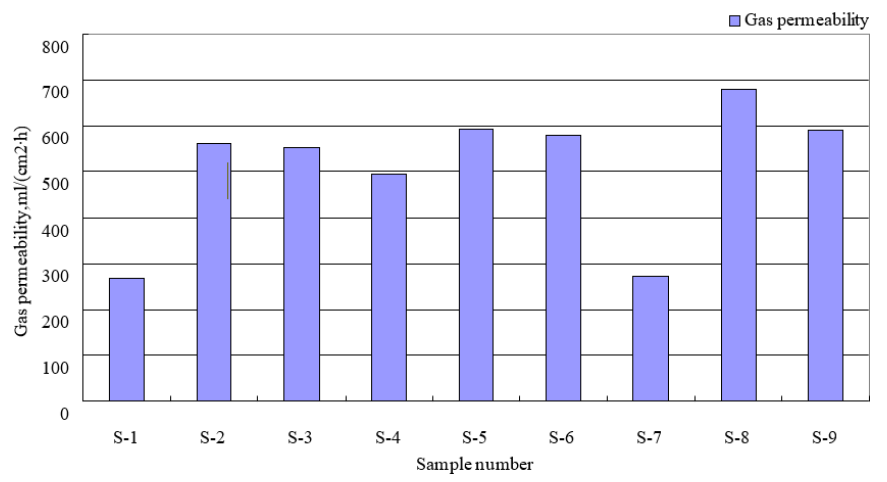

Figure 15. Gas permeability

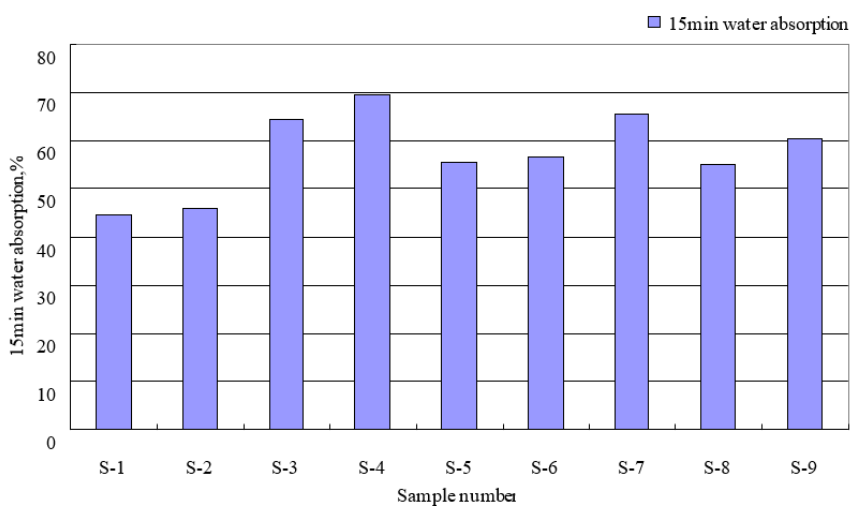

Figure 16. 15min water absorption

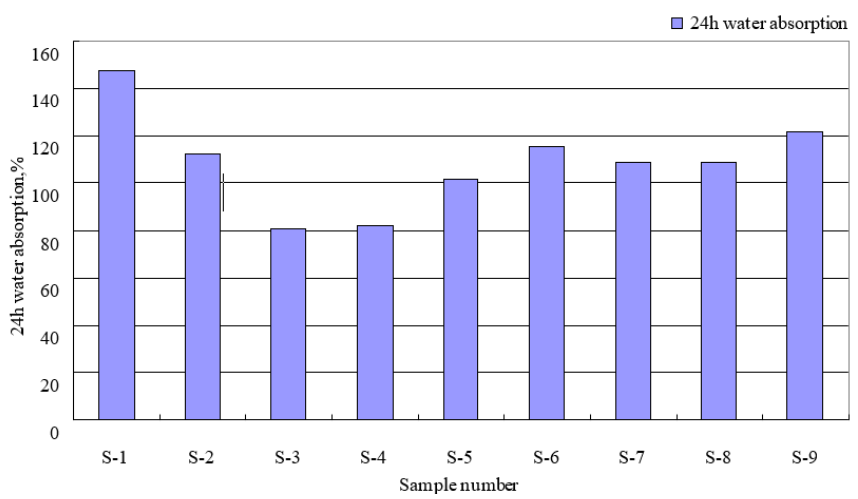

Figure 17. 24h water absorption
As shown in Figure 15, all samples exhibited good gas permeability except S-1 and S-7. The sample S-1 had poor gas permeability, because the plate was not well formed due to low latex ratio, water ratio and hot-pressing temperature. Despite its high latex ratio, the sample S-7 still had a low gas permeability, for the plate was not well formed under the low water ratio, which hinders the uniform mixing of the latex and the shavings.

Figures 16 and 17 show that the GFGL plates made of natural rubber latex enjoy excellent water absorption, which improves with the elapse of time. This is because natural rubber latex and shavings are both hydrophilic materials. After hot-pressing, the network structure of the two materials is bound to have a high-water absorption. Thus, the GFGL plates made of natural rubber latex are desirable materials for insole board.

\subsubsection{Microstructure observation}

Figures 18 21 present the SEM images of typical samples S-1, S-2, S-3 and S-9, respectively, with the magnification of 3,000 times.

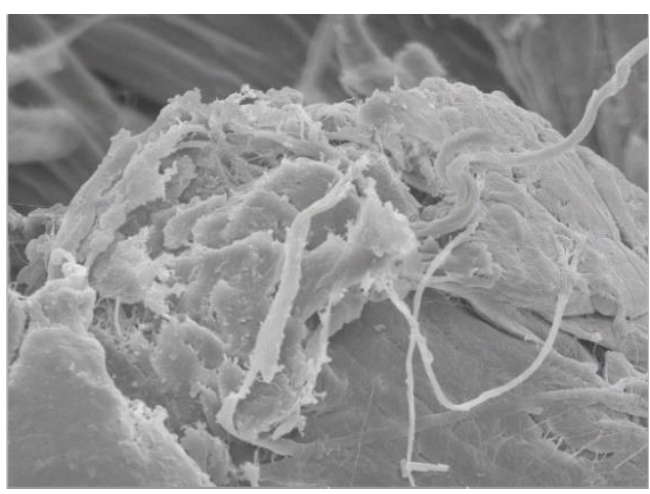

Figure 18. The SEM image of S-1

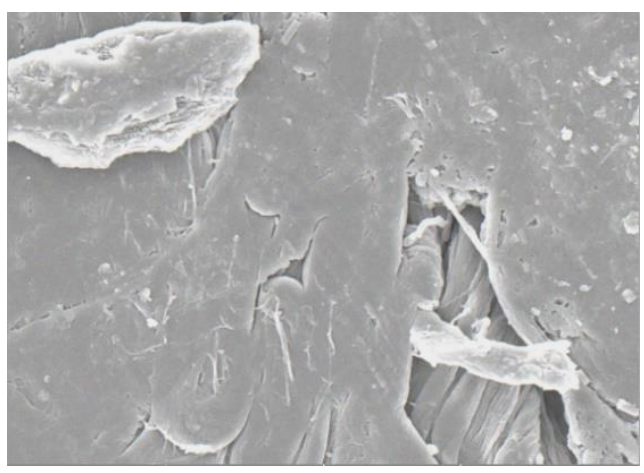

Figure 19. The SEM image of $\mathrm{S}-2$

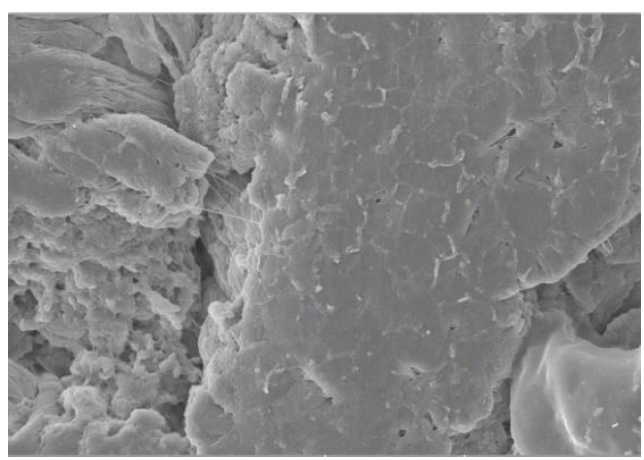

Figure 20. The SEM image of S-3 


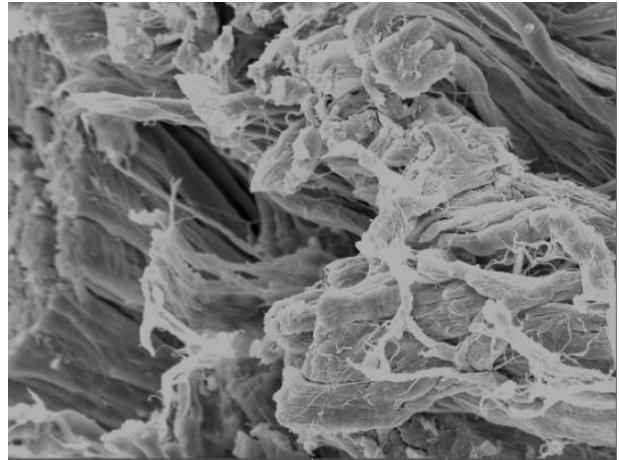

Figure 21. The SEM image of S-9

In the above figures, S-2 and S-3 showed integrated network structures, which was formed through the intense chemical reactions between the natural rubber latex and the shavings under stirring and hot-pressing. By contrast, the latex and the shavings were not well bonded in S-1 and S-9. The results are consistent with the analysis on tensile strength and gas permeability.

Considering the SEM results and the orthogonal test, the hot-pressing parameters of S-5 and S- 6 were determined as the optimal settings for basic hot-pressing.

\section{CONCLUSIONS}

The above analysis shows that it is feasible to produce GFGL plates through hot-pressing on a flat vulcanizing machine. This dry machining method is simple and costeffective, and can effectively recycle chrome shavings, without causing any secondary pollution to the environment.

The optimal hot-pressing conditions and formula for GFGL plates made of natural rubber latex were determined as follows: (1) latex ratio $15 \%$, water ratio $2: 1,110{ }^{\circ} \mathrm{C}, 6 \mathrm{~min}$ and $5 \mathrm{MPa}$; (2) latex ratio $21 \%$, water ratio $2.5: 1,100{ }^{\circ} \mathrm{C}, 4 \mathrm{~min}$ and $5 \mathrm{MPa}$.

Under these settings, the preliminary plates enjoy good gas permeability and water absorption, and enough tensile strength and rupture strength. If toughed by plant fibers, these plates can be adopted to produce insole board in footwear industry.

\section{ACKNOWLEDGMENT}

This work is supported by Key projects of natural science research in Hebei higher education institutions; Application innovation project in Xingtai Polytechnic College

\section{REFERENCES}

[1] Li, D., Li, G.Y., Jiang, D.Y., Yu, J.X. (2008). Extracting of native collagen from bovine limed split wastes: Pretreatment and extraction. China Leather, 37(9): 8-11. https://doi.org/10.13536/j.cnki.issn10016813.2008.09.003

[2] Alexander, K.T.W., Corning, D.R., Cory, N.J., Donohue, V.J., Sykes, R.L. (2002). Environmental and safety issueclean technology and environmental auditing. Journal of the Society of Leather Technologists and Chemists, 76(1): 17-23.

[3] Tahiri, S., Albizane, A.A., Messaoudi, A., Azzi, M.,
Mohamed, M.B., Sibari, A. (2001). Processing of chrome tanned solid waste generated in leather industry: Recover of proteins and synthesis of a pigment for paint. JournalAmerican Leather Chemists Association, 96(1): 1-8. https://doi.org/10.1017/S0140525X00057368

[4] Huc, A. (1985). Collagen biomaterials characteristics and application. Journal-American Leather Chemists Association, $80(7)$ : 195-212. https://doi.org/10.1017/S1431927605500011

[5] Cabeza, L.F., Taylor, M.M., Brown, E., Marmer, W.N. (1999). Isolation of protein products from chromium containing leather waste using two consecutive enzymes and purifaction of find chromium product: Pilot plant studies. Journal-Society of Leather Technologists and Chemists, 83(1): 14-19.

[6] Taylor, M.M., Diefendor, E.J., Thompson, C.J., Brown, E., Marmer, W.N., Cabeza, L.F. (1997). Extraction of value added by products from the treatment of chromium containing collagenous leather industry waste. Journal of the Society of Leather Technologists and Chemists, 81(1): 5-13.

[7] Chen, W., Huang, Z., Lin, L., Feng, H. (2002). Studies on extracting collagen from chrome shavings. China Leather, 31(23): 1-5. https://doi.org/10.3969/j.issn.10016813.2002.23.001

[8] Chen, Y., Ding, Z. (2007). Study on graftcopolymerization modification of collagen protein. $\begin{array}{lll}\text { China } & \text { Leather, } & \text { 36(23): }\end{array}$ https://doi.org/10.13536/j.cnki.issn10016813.2007.23.010

[9] Jia, P.X., Tang, K.Y. (2006). An acrylic retanning agent modified by collagen. Fine Chemicals, 23(8): 801-805. https://doi.org/10.3321/j.issn:1003-5214.2006.08.020

[10] Farouk, M.M., Price, J.F., Salih, A.M. (1990). Effect of edible collagen film overwrap on exudation and lipid oxidation in beef round steak. Journal of Food Science, 55(6): 1510-1512. https://doi.org/10.1111/j.13652621.1990.tb03556.x

[11] Fu, L., Zhang, M., Qi, Y., Qiu, H. (2002). Bonding mechanism of collagen protein and cellulose base fibers. Transactions of China Pulp and Paper, 17(1): 68-71. https://doi.org/10.3321/j.issn:1000-6842.2002.01.016

[12] Wang, K., Pan, Z., Chen, J. (2002). Application of collagen protein in medical wound dressing. Leather Science and Engineering, 12(1): 46-49. https://doi.org/10.3969/j.issn.1004-7964.2002.01.012

[13] Ma, C., Shu, Z., Lin, W., Wang, B., Zhang, M. (2001). Progress in edible collagen packaging film. China Leather, 30(5): 8-10. https://doi.org/10.3969/j.issn.10016813.2001.05.002

[14] Fu, Y., Shen, X. (2004). Discussion on the utilization of fish skin collagen. Food Research and Development, 25(2): 16-18. https://doi.org/10.3969/j.issn.10056521.2004.02.005

[15] Cheng, Y., Sun, X., Liao, X., Zeng, F., Wu, Y., Shi, B. (2011). Adsorption of uranium from wastewater containing fluorine and uranium by collagen fiber immobilized titanium. Ciesc Journa, 62(2): 386-391.

[16] Taylor, M.M. (1998). Processing of leather waste: Pilot scale studies on chrome shavings(I): isolation and characterization of protein products and separation of Chrome cake. Journal-American Leather Chemists Association, 93(10): 332-332. 